\title{
Platelet-activating Factor (PAF) Stimulates the Production of PAF Acetylhydrolase by the Human Hepatoma Cell Line, HepG2
}

\author{
Kei Satoh, Tada-atsu Imaizumi, Yoko Kawamura, Hidemi Yoshida, Makoto Hiramoto, \\ Shigeru Takamatsu, and Mutsu Takamatsu* \\ Department of Pathologic Physiology, Institute of Neurological Diseases, Hirosaki University School of Medicine, 5-Zaifucho, Hirosaki \\ 036, Japan; *Training Course of School Nursing, Faculty of Education, Hirosaki University, 1-Bunkyocho, Hirosaki 036, Japan
}

\begin{abstract}
The human hepatoma cell line, HepG2, secreted an activity that degrades platelet-activating factor (PAF) by the hydrolysis of the $s n-2$ acetyl group. This activity was $\mathrm{Ca}^{++}$independent, inhibited by diisopropylfluorophosphate but not by $p$-bromophenacyl bromide, and resistant to treatment with trypsin or pronase. Separation of HepG2-conditioned medium by gel filtration disclosed that the activity was associated with lipoproteins. An antiserum against PAF acetylhydrolase immunoprecipitated this activity. It was not recognized by an antibody against lecithin:cholesterol acyltransferase (LCAT), which also is secreted by HepG2 cells. Therefore the phospholipase $A_{2}$ activity of LCAT was excluded as a source of the observed activity. PAF added to the culture medium stimulated the secretion of the PAF-degrading activity by HepG2 cells, while lyso-PAF was inactive. Maximal stimulation was observed with $5 \mathrm{ng} / \mathrm{ml}$ PAF, which induced a fivefold increase. The presence of $5 \mathrm{ng} / \mathrm{ml}$ PAF enhanced the secretion of $\left[{ }^{35}\right.$ S]methioninelabeled PAF acetylhydrolase and cycloheximide inhibited both the basal and PAF-stimulated secretion of the labeled enzyme.

We conclude that HepG2 cells produce PAF acetylhydrolase. The liver may be a major source of plasma PAF acetylhydrolase, and PAF may induce the production of its inactivating enzyme by the liver. (J. Clin. Invest. 1991. 87:476-481.) Key words: lipoproteins - lecithin:cholesterol acyltransferase (LCAT) • phospholipase $A_{2} \cdot$ liver $\bullet$ metabolic labeling
\end{abstract}

\section{Introduction}

Platelet-activating factor (PAF) ${ }^{1}$ is a bioactive phospholipid produced by various types of cells in response to an appropriate agonist $(1,2)$. PAF has been identified as 1-alkyl-2-acetyl-snglycero-3-phosphocholine (3) and is metabolized through the

\footnotetext{
Address correspondence and reprint requests to Dr. Kei Satoh, Department of Pathologic Physiology, Institute of Neurological Diseases, Hirosaki University School of Medicine, 5-Zaifucho, Hirosaki 036, Japan.

Received for publication 5 December 1989 and in revised form 25 September 1990

1. Abbreviations used in this paper: apo, apolipoprotein; BPB, p-bromophenacyl bromide; DFP, diisopropylfluorophosphate; GPC, glycero-3-phosphocholine; LCAT, lecithin:cholesterol acyltransferase; LDH, lactic dehydrogenase; PAF, platelet-activating factor; PC, phosphatidylcholine.
}

J. Clin. Invest.

(c) The American Society for Clinical Investigation, Inc. 0021-9738/91/02/0476/06 \$2.00

Volume 87, February 1991, 476-481 hydrolytic cleavage of the $s n-2$ acetyl moiety by a specific enzyme, PAF acetylhydrolase $(4,5)$. There are intra- and extracellular forms of this enzyme (6), and they may play an important role as a mechanism to regulate the levels of PAF. The activity of this enzyme in plasma has been reported to be higher in patients with dyslipoproteinemia (7), atherosclerotic diseases (8), ischemic stroke (9), and essential hypertension (10). It is reported to be lower in patients with severe bronchial asthma (11). It has also been suggested that a decreased plasma PAF acetylhydrolase activity in late pregnancy is related to the initiation of labor (12). However, the mechanism and significance of the alterations of plasma PAF acetylhydrolase activity have not been fully elucidated. In plasma this enzyme is associated with LDL and HDL $(13,14)$. This suggests that plasma PAF acetylhydrolase is produced and released by the liver, as a complex with lipoproteins. We examined the production of PAF acetylhydrolase by the human hepatoma cell line, HepG2 (15), which retains many aspects of normal functions of human hepatocytes including lipoprotein metabolism (16-22). Special reference was made to the differentiation of the PAF acetylhydrolase activity from the phospholipase $A_{2}$ activity of lecithin:cholesterol acyltransferase (LCAT), which is also produced by HepG2 cells (23). The effect of PAF on the production of PAF acetylhydrolase was also studied.

\section{Methods}

Chemicals. Culture medium, FCS, antibiotics, and other reagents for cell culture were obtained from Gibco Laboratories (Grand Island, NY). [2-Acetyl- $\left.{ }^{3} \mathrm{H}\right] \mathrm{PAF}(370 \mathrm{GBq} / \mathrm{mmol}$ or $10 \mathrm{Ci} / \mathrm{mmol}),\left[4-{ }^{14} \mathrm{C}\right] \mathrm{cho}-$ lesterol $(2.22 \mathrm{MBq} / \mathrm{mmol})$, and $\left.{ }^{{ }^{3}} \mathrm{~S}\right]$ methionine $(46.07 \mathrm{TeraBq} / \mathrm{mmol})$ were from New England Nuclear (Boston, MA). Unlabeled PAF, lysoPAF, and other phospholipids were from Sigma Chemical Co. (St. Louis, MO), which also supplied apolipoprotein (apo) A-I, fatty acidfree HSA, diisopropylfluorophosphate (DFP), $p$-bromophenacyl bromide (BPB), and protein A-Sepharose CL 4B. Octadecylsilica gel cartridges $\left(C_{18}\right.$ Pre Sep) were purchased from Gasukuro Kogyo (Tokyo, Japan). Rabbit antisera against human apo A-I or apo B were obtained from Daiichi Pure Chemical (Tokyo, Japan). Rabbit antiserum against PAF acetylhydrolase (24) and a monoclonal antibody against LCAT (25) were generous gifts from Dr. Diana Stafforini (University of Utah) and Dr. Angelo Scanu (University of Chicago), respectively. Nonimmune rabbit IgG was from Zymed Laboratories (San Francisco, CA). A specific receptor antagonist of PAF, CV-3988 (26), was generously provided by the Central Research Division, Takeda Chemical Industries (Osaka, Japan).

Cell culture. HepG2 cells were obtained from the American Type Culture Collection (Rockville, MD) and maintained in 35- $\mathrm{mm}$ dishes (Falcon Labware, Oxnard, CA) using Eagle's MEM supplemented with $10 \%$ (vol/vol) FCS, $0.1 \mathrm{mM}$ nonessential amino acids, $1 \mathrm{mM}$ sodium pyruvate, $100 \mathrm{U} / \mathrm{ml}$ penicillin $\mathrm{G}$, and $100 \mu \mathrm{g} / \mathrm{ml}$ streptomycin. Cells were incubated in a humidified atmosphere of $95 \%$ air and $5 \%$ $\mathrm{CO}_{2}$. Viability of the cells was assessed by the trypan blue exclusion method (27). 
After the cells had reached confluence, the monolayers were washed twice with HBSS, and fresh medium without FCS was added. After incubating for up to $36 \mathrm{~h}$ (usually $24 \mathrm{~h}$ ), the medium was recovered and assayed for PAF acetylhydrolase activity. In the experiments to examine the effects of PAF or lyso-PAF, these phospholipids were dissolved in $20 \mathrm{mM}$ PBS, $\mathrm{pH} 7.4$, containing $2.5 \mathrm{mg} / \mathrm{ml} \mathrm{HSA}$, and $1 / 10 \mathrm{vol}$ of either solution was added to the culture medium. The possible inhibition of the effect of PAF by PAF antagonist CV-3988 (26) was also tested. CV-3988 was dissolved in HBSS by warming to $50^{\circ} \mathrm{C}$ and the solution was added to the culture medium at the final concentration of $1 \mu \mathrm{M}$. HepG2 cells were incubated with CV-3988 for $1 \mathrm{~h}$ before the addition of PAF.

To obtain the sample for chromatographic separation of the enzyme, HepG2 cells were cultured in $75-\mathrm{cm}^{2}$ tissue culture flasks (Falcon Labware), and the supernatants from 10 flasks were combined and concentrated using Immersible CX-10 ultrafiltration units (Millipore Continental Water Systems, Bedford, MA).

$P A F$ acetylhydrolase assay. PAF acetylhydrolase activity in the conditioned medium was assayed according to Stafforini and coworkers (28) with a slight modification. Each assay mixture contained 10-30 $\mu \mathrm{l}$ of HepG2-conditioned medium and $5 \mu \mathrm{l}$ of substrate ([2acetyl- $\left.{ }^{3} \mathrm{H}\right] \mathrm{PAF}$ ), and the final volume was adjusted to $50 \mu \mathrm{l}$ with $0.1 \mathrm{M}$ Hepes buffer, $\mathrm{pH}$ 7.2. The final concentration of the substrate was 80 $\mu \mathrm{M}$. The substrate was prepared in Hepes buffer, by sonication, with a final specific activity of $5 \times 10^{4} \mathrm{dpm} / \mathrm{nmol}$. Reactions were performed at $37^{\circ} \mathrm{C}$ for $30 \mathrm{~min}$ and stopped by adding $50 \mu \mathrm{l}$ of $10 \mathrm{M}$ acetic acid. This mixture was applied to an octadecylsilica gel cartridge, which was then washed three times with $1.0 \mathrm{ml}$ of $0.1 \mathrm{M}$ sodium acetate. The washes were collected into a scintillation vial and the radioactivity was determined. The effects of proteases, EDTA, and DFP on the PAF-degrading activity were tested as described $(6,28)$. The effect of BPB, an inhibitor of phospholipase $A_{2}(29)$, was also studied. BPB dissolved in ethanol was added to the conditioned medium and the mixture was incubated $30 \mathrm{~min}$ at room temperature. The final concentration of ethanol was $0.1 \%$. The substrate specificity of the assay was examined by adding phospholipid molecules other than PAF. They were lysoPAF, 1-hexadecyl-2-oleyl-rac-glycero-3-phosphocholine (1-hexadecyl2-oleyl-GPC), egg yolk phosphatidylcholine (PC) and egg yolk phosphatidylethanolamine (PE). These phospholipids were solubilized in HBSS by sonication and added to the substrate solution.

Gel filtration chromatography. Chromatographic separation of HepG2-conditioned medium was performed using a fast protein liquid chromatography system (Pharmacia Fine Chemicals, Uppsala, Sweden) equipped with a gel permeation column TSK-GEL G5000PW $+\mathrm{G} 3000 \mathrm{SW} \times 2$ (Toyo Soda, Japan) (30). Elution was performed with $20 \mathrm{mM}$ Tris- $\mathrm{HCl}$ buffer, $\mathrm{pH} 7.4$, at a flow rate of $0.2 \mathrm{ml} / \mathrm{min}$. Fractions of 5 min were collected, and each fraction was assayed for PAF acetylhydrolase in a similar manner. Contents of apo A-I and apo B in each fraction were measured by single radial immunodiffusion using specific antisera.

LCAT assay. HepG2-conditioned medium was also assayed for LCAT activity according to Chen et al. (23) with a slight modification. A liposome with a phosphatidylcholine:cholesterol:apo A-I molar ratio of 250:12.5:0.6 was prepared by the cholate dialysis method (31), for use as the substrate. The specific activity of $\left[{ }^{3} \mathrm{H}\right]$ cholesterol in this substrate was adjusted to $7.4 \mathrm{MBq} / \mathrm{mmol}$. Each assay mixture contained $500 \mathrm{nmol}$ phosphatidylcholine, $25 \mathrm{nmol}$ cholesterol, $5 \%$ (wt/vol) HSA $5 \mathrm{mmol} 2$-mercaptoethanol, $1.2 \mathrm{nmol}$ apo A-I, and $200 \mu \mathrm{l}$ of a sample.

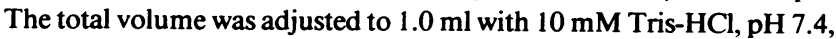
containing $140 \mathrm{mM} \mathrm{NaCl}$ and $1 \mathrm{mM}$ EDTA. The reaction was performed for $2 \mathrm{~h}$ at $37^{\circ} \mathrm{C}$ and stopped by adding $3.25 \mathrm{ml}$ of chloroformmethanol $(2: 1)$. Lipids were extracted and separated by thin layer chromatography as described by Verdery and Gatt (32). The area of silica gel corresponding to cholesterol ester was scraped into a vial and the radioactivity was measured by scintillation spectrometry.

Immunoprecipitation. To identify the PAF hydrolyzing activity as PAF acetylhydrolase, HepG2-conditioned medium was treated with either anti-PAF acetylhydrolase or anti-LCAT antibodies. Before use, these antibodies were treated with DFP to abolish the endogenous PAF acetylhydrolase activity and the remaining DFP was removed by dialysis against PBS. HepG2-conditioned medium was concentrated $\sim 5$ fold using an ultrafiltration unit. To this concentrate, an equal volume of the antibody solution, diluted 20-fold with PBS, was added and the mixture was incubated overnight at $4^{\circ} \mathrm{C}$. To $200 \mu \mathrm{l}$ of this mixture, 50 $\mu \mathrm{l}$ of $50 \%(\mathrm{vol} / \mathrm{vol})$ suspension of protein A-Sepharose in PBS was added, and the mixture was further incubated for $1 \mathrm{~h}$ at $4^{\circ} \mathrm{C}$. After brief centrifugation, the supernatant was assayed for PAF acetylhydrolase or LCAT.

Biosynthetic labeling of HepG2 proteins. HepG2 cells grown in a 35-mm dish were incubated with $1 \mathrm{MBq} / \mathrm{ml}\left[{ }^{35} \mathrm{~S}\right]$ methionine in methionine-free MEM in the presence or absence of PAF $(5 \mathrm{ng} / \mathrm{ml})$. The effect of cycloheximide, an inhibitor of protein synthesis, was also studied. Cycloheximide was dissolved in HBSS and $10 \mu$ lof the solution was added to the culture medium to achieve a final concentration of 10 $\mu \mathrm{g} / \mathrm{ml}$. After $24 \mathrm{~h}$, the conditioned medium was recovered. The total labeling of secreted proteins was determined using an aliquot $(200 \mu \mathrm{l})$ of the conditioned medium. To $200 \mu$ l of the conditioned medium, 1 $\mathrm{ml}$ of albumin solution $(5 \mathrm{mg} / \mathrm{ml})$ was added and proteins were precipitated by adding $1 \mathrm{ml}$ of $50 \%$ TCA. After centrifugation at 3,000 rpm for $10 \mathrm{~min}$, the pellet was washed vigorously with distilled water, redissolved with $2 \mathrm{M} \mathrm{NaOH}$ and counted by scintillation spectrometry. The remainder of the conditioned medium was used for immunoprecipitation and electrophoresis.

Immunoprecipitation and electrophoresis of $\left[{ }^{35} S\right]$ methionine-labeled proteins. IgG was purified from the anti-PAF acetylhydrolase antiserum by protein A-Sepharose chromatography (33), dialyzed against PBS and finally diluted with PBS so that the volume would be 10 times of the original antiserum. To $800 \mu$ l of the conditioned medium, $10 \mu \mathrm{l}$ of the IgG fraction was added and the mixture was incubated for $6 \mathrm{~h}$ at $4^{\circ} \mathrm{C}$. Then $50 \mu \mathrm{l}$ of $50 \%$ suspension of protein A-Sepharose was added and the mixture was further incubated for $1 \mathrm{~h}$ at $4^{\circ} \mathrm{C}$. The mixture was centrifuged at $3,000 \mathrm{rpm}$ for $10 \mathrm{~min}$, and the pellet was washed 10 times with $10 \mathrm{ml}$ of PBS. The final pellet was subjected to either counting with a scintillation counter or SDS-PAGE. For a control experiment, nonimmune rabbit IgG was substituted for the specific immune IgG.

SDS-PAGE was carried out on $10 \%$ slab gels (34). Immunoprecipitates were suspended in $50 \mu \mathrm{l}$ of $25 \mathrm{mM}$ Tris-glycine buffer (pH 8.3) containing $2 \%(\mathrm{wt} / \mathrm{vol}$ ) SDS, $10 \mathrm{mM}$ dithiothreitol, and $10 \%$ (vol/vol) glycerol, and heated for $3 \mathrm{~min}$ in a boiling water bath before being applied to the gel. Gels were run at $50 \mathrm{~V}$ constant voltage for $\sim 1 \mathrm{~h}$. Gels were fixed and stained as described (35). Gels were immersed for $30 \mathrm{~min}$ in $200 \mathrm{ml}$ of DMSO twice and then in $100 \mathrm{ml}$ of $20 \%(\mathrm{wt} / \mathrm{wt})$ diphenyloxazole in DMSO for $3 \mathrm{~h}$. After soaking in $200 \mathrm{ml}$ of distilled water for $1 \mathrm{~h}$, the gel was dried and exposed to a Kodak X-Omat film at $-80^{\circ} \mathrm{C}$ for $7 \mathrm{~d}$.

Lactic dehydrogenase as a cytotoxicity assay. Possible cytotoxic effects of PAF or cycloheximide were checked by monitoring the release of lactic dehydrogenase (LDH) into the conditioned medium (36). LDH activity was determined using a commercially available reagent kit (Wako Pure Chemicals, Osaka, Japan).

Quantification of cellular protein. Monolayers of HepG2 cells were solubilized by incubating them with sodium hydroxide solution. To a 35-mm dish, $2 \mathrm{ml}$ of $0.2 \mathrm{M}$ sodium hydroxide was added and the dish was incubated at room temperature for $1 \mathrm{~h}$. Then the solution was recovered and the dish was washed three times with $1 \mathrm{ml}$ of the sodium hydroxide solution. All of these solutions were combined and further incubated at room temperature for $1 \mathrm{~h}$. An aliquot (50-200 $\mu \mathrm{l})$ of this solution was used for protein quantification according to Lowry et al. (37).

\section{Results}

The release of $\left[{ }^{3} \mathrm{H}\right]$ acetate from $\left[2\right.$-acetyl- $\left.{ }^{3} \mathrm{H}\right] \mathrm{PAF}$ by incubation with HepG2-conditioned medium is shown in Fig. 1. This 


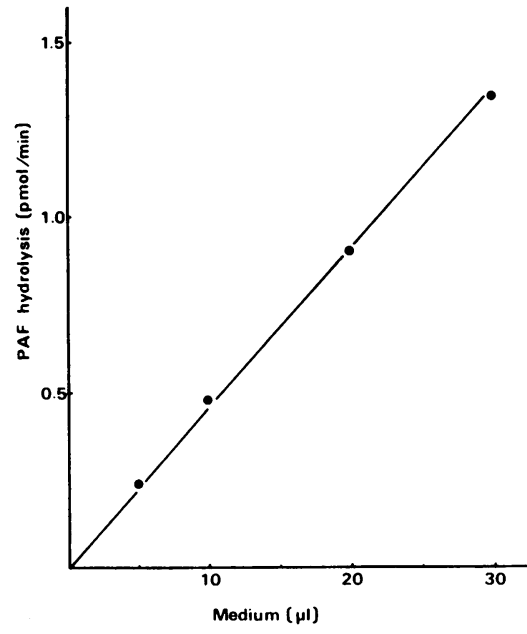

Figure 1. PAF hydrolyzing activity in HepG2-conditioned medium. The culture medium conditioned by HepG 2 cells for $24 \mathrm{~h}$ was assayed for [2acetyl- $\left.{ }^{3} \mathrm{H}\right] \mathrm{PAF}$ degrading activity as described in Methods. This activity was found to be linear with the amount of sample ranging from 5 to $30 \mu$.

reaction was dependent on the period of incubation and on the amount of medium up to a protein content in the assay of $20 \mu \mathrm{g}$.

The effect of DFP, EDTA, BPB, proteases, and various phospholipids on the activity are summarized in Table I. DFP inhibited the PAF acetylhydrolase activity in a concentrationdependent manner and the inhibition at $1 \mathrm{mM}$ was almost complete. EDTA and BPB had no effect on the PAF acetylhydrolase activity in HepG2-conditioned medium. Preincubation of the medium with either trypsin or pronase also did not affect the activity. The possible effect of protease inhibitors in the medium was excluded by a control experiment in which more than $90 \%$ of added protease activity was detected, by a caseinolytic assay, in the samples after the incubation (data not shown). Lyso-PAF or other phospholipids also did not affect the assay.

Table I. Effects of DFP, EDTA, BPB, Proteases, and Various Forms of Phospholipids on the PAF Acetylhydrolase Activity in HepG2-conditioned Medium

\begin{tabular}{lll}
\hline \multicolumn{1}{c}{ Treatment } & & $\begin{array}{c}\text { PAF acetylhydrolase } \\
\text { (percent of control) }\end{array}$ \\
\hline DFP & $0.1 \mathrm{mM}$ & 32,54 \\
& $1.0 \mathrm{mM}$ & 8,4 \\
EDTA & $10 \mathrm{mM}$ & 100,113 \\
BPB & $10 \mu \mathrm{M}$ & 115,113 \\
Trypsin* & $1 \mathrm{mg} / \mathrm{ml}$ & 102,109 \\
Pronase* & $1 \mathrm{mg} / \mathrm{ml}$ & 111,98 \\
Egg yolk PC & $0.1 \mathrm{mM}$ & 89,94 \\
& $0.5 \mathrm{mM}$ & 95,100 \\
Egg yolk PE & $0.1 \mathrm{mM}$ & 97,103 \\
& $0.5 \mathrm{mM}$ & 96,98 \\
1-Hexadecyl-2-oleyl-GPC & $0.1 \mathrm{mM}$ & 102,105 \\
& $0.5 \mathrm{mM}$ & 95,100 \\
\hline
\end{tabular}

HepG2 cells were incubated in serum-free medium for $24 \mathrm{~h}$ and the conditioned medium was assayed for PAF acetylhydrolase. The values of two separate experiments, each with duplicate determinations, are shown. ${ }^{*}$ HepG2-conditioned medium was incubated with the proteases for $30 \mathrm{~min}$ at $37^{\circ} \mathrm{C}$ before addition of the substrate for assay of PAF acetylhydrolase activity. ${ }^{*}$ These phospholipids were dissolved in PBS by sonication and added to the substrate solution.

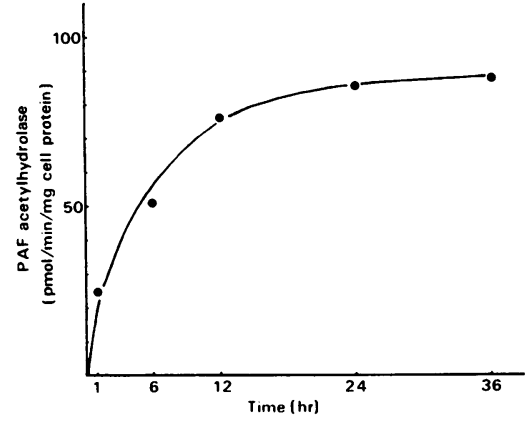

Figure 2. Timedependent secretion of PAF acetylhydrolase by HepG2 cells. HepG2 cells were cultured for up to $36 \mathrm{~h}$ in serum-free medium. PAF acetylhydrolase activity in the conditioned medium increased gradually until $24 \mathrm{~h}$ and plateaued thereafter.

Production of PAF acetylhydrolase by HepG2 cells as a function of time in culture is shown in Fig. 2. PAF acetylhydrolase activity in the medium plateaued at $24 \mathrm{~h}$ of incubation, after which time the activity was unchanged for up to $36 \mathrm{~h}$. After $36 \mathrm{~h}$ of incubation in the medium without FCS, the viability of the cells tested by a dye exclusion assay was $92 \%$, which was slightly lower than that of the cells at $24 \mathrm{~h}: 97 \%(n=2)$. Thus the decreased secretion of the activity after $36 \mathrm{~h}$ of incubation may have been due to the poor ability of the serum-free medium to support normal cellular functions. Therefore, in the following experiments HepG2 cells were incubated in the serum-free medium for $24 \mathrm{~h}$.

Separation of HepG2-conditioned medium by gel permeation high performance liquid chromatography is shown in Fig. 3. PAF acetylhydrolase activity was recovered in the fractions that had an elution volume that corresponded to that of plasma lipoproteins. The elution of the activity coincided with the fractions that contained either apo A-I or apo B.

The results of immunoprecipitation experiments are summarized in Table II. When the conditioned medium was precipitated with the anti-PAF acetylhydrolase antiserum and protein A-Sepharose, the supernatant did not hydrolyze PAF, whereas most of the LCAT activity remained in solution. The immunoprecipitation using the anti-LCAT antibody resulted in the opposite pattern: LCAT was precipitated by the antibody while PAF acetylhydrolase activity was not.

The effect of PAF on the secretion of PAF acetylhydrolase by HepG2 cells is shown in Fig. 4. Under basal conditions, HepG2 cells secreted PAF acetylhydrolase at a rate such that at the end of $24 \mathrm{~h}$ there was a total activity of $12 \pm 14 \mathrm{pmol} / \mathrm{min}$ per $\mathrm{mg}$ cell protein. PAF at concentrations of $0.1-10 \mathrm{ng} / \mathrm{ml}$ (0.18-18 $\mathrm{nM})$ stimulated the secretion of the enzyme and the maximal effect was observed with $5 \mathrm{ng} / \mathrm{ml}(9 \mathrm{nM})$ PAF, which induced an approximately fivefold increase. PAF was inhibitory at $50 \mathrm{ng} / \mathrm{ml}$. At this concentration, PAF was found to be toxic to the cells since the dye exclusion test disclosed only $82 \%$ cell viability after $24 \mathrm{~h}$ of incubation $(n=2)$. Lyso-PAF or egg yolk PC, added to the culture medium at a concentration of either 5 or $50 \mathrm{ng} / \mathrm{ml}$ did not affect the secretion of PAF acetylhydrolase by HepG 2 cells (data not shown). The stimulatory effect of $5 \mathrm{ng} / \mathrm{ml}(9 \mathrm{nM})$ PAF was abolished by pretreating

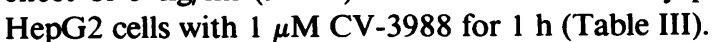

The results of biosynthetic labeling are shown in Table IV. Under basal conditions, HepG2 secreted $\left.{ }^{35} \mathrm{~S}\right]$ methioninelabeled PAF acetylhydrolase of $3.9 \pm 1.8 \mathrm{fmol} / \mathrm{mg}$ cell protein in $24 \mathrm{~h}(n=7)$, which corresponded to $0.22 \%$ of the total secreted proteins labeled. Labeling of PAF acetylhydrolase was increased significantly $(P<0.01)$ by $5 \mathrm{ng} / \mathrm{ml}$ PAF: $9.6 \pm 4.2 \mathrm{fmol} /$ $\mathrm{mg}$ cell protein, and this corresponded to only $0.30 \%$ of the 

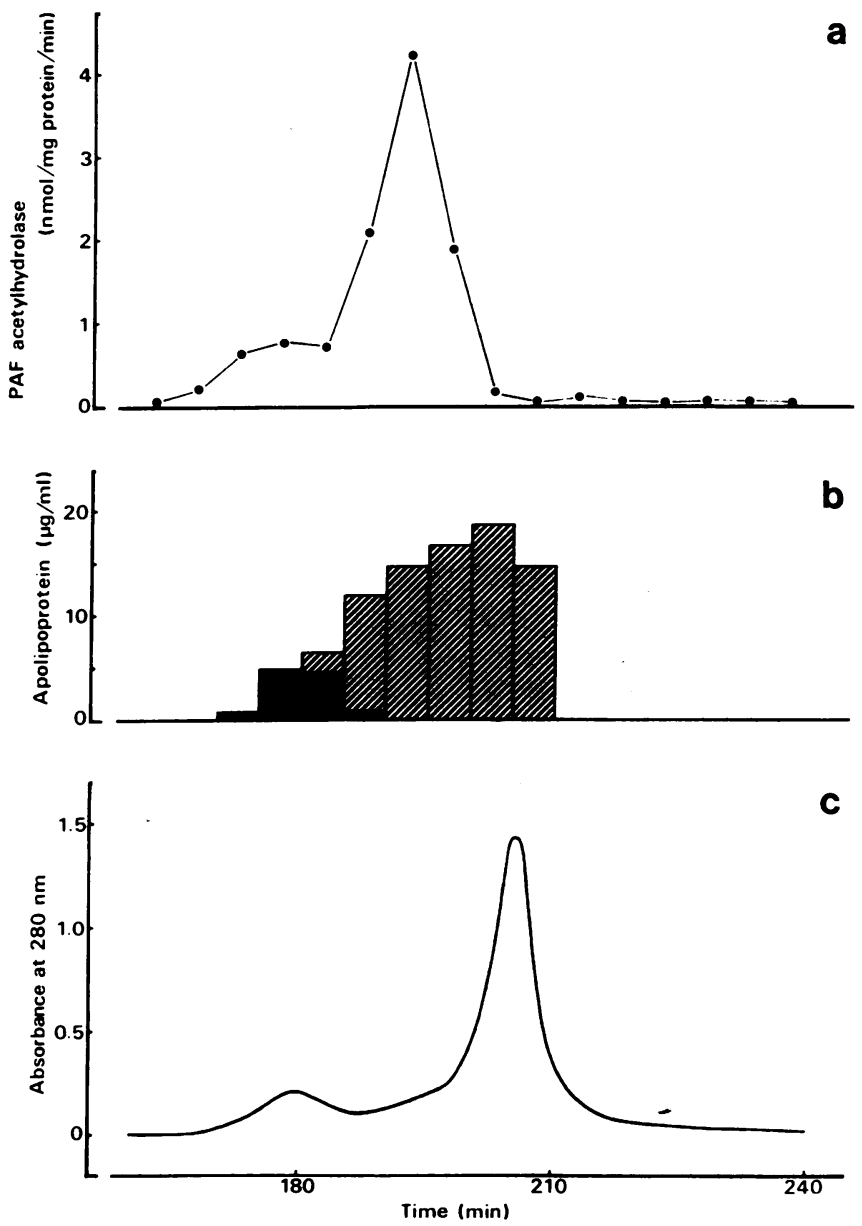

Figure 3. Gel filtration chromatography of the HepG2-conditioned medium. The conditioned medium recovered from twenty $75-\mathrm{cm}^{2}$ flasks was concentrated, and then fractionated by a fast protein liquid chromatography system equipped with a gel filtration column (TSK GEL G5000PW + G3000SW $\times 2$ ). Elution was performed with 10 $\mathrm{mM}$ phosphate buffer $(\mathrm{pH} 7.2)$ at a flow rate of $0.2 \mathrm{ml} / \mathrm{min}$. Fractions of $10 \mathrm{ml}$ were collected and assayed for PAF acetylhydrolase activity. (a) PAF acetylhydrolase activity. (b) Contents of apo A-I (hatched columns) and apo B (black columns). (c) Elution profile of protein as monitored by absorption at $280 \mathrm{~nm}$.

total labeling because PAF enhanced the labeling of total secreted proteins as well. Cycloheximide inhibited the incorporation of $\left[{ }^{35} \mathrm{~S}\right]$ methionine in secreted proteins and abolished the stimulatory effect of PAF. These effects of PAF and cycloheximide were also confirmed by SDS-PAGE as shown in Fig. 5 . Although a few minor bands were seen on the fluorogram of the gel, there was an obvious increase in the density of the major band around 45,000 D, which is consistent with plasma PAF acetylhydrolase (24). The effects of PAF and cycloheximide were not due to cytoxicity of these compounds since the extracellular release of $\mathrm{LDH}$, an indicator of cytolysis (36), was not increased in the presence of PAF and/or cycloheximide (Table IV).

\section{Discussion}

In this study, we demonstrated the production of PAF acetylhydrolase by HepG2 cells. PAF acetylhydrolase is a degrading
Table II. Immunological Identification of PAF Acetylhydrolase in HepG2-conditioned Medium

\begin{tabular}{lcc}
\hline & \multicolumn{2}{c}{ Activity (percent of control) } \\
\cline { 2 - 3 } \multicolumn{1}{c}{ Antibody } & PAF acetylhydrolase & LCAT \\
\hline Anti-PAF acetylhydrolase & $3 \pm 2.7$ & $89 \pm 20.4$ \\
Anti-LCAT & $108 \pm 11.3$ & $11 \pm 2.9$ \\
\end{tabular}

HepG2-conditioned medium was incubated with either anti-PAF acetylhydrolase or anti-LCAT overnight, a suspension of protein A-Sepharose was added, and the supernatant was assayed for PAF acetylhydrolase or LCAT. In the control experiment the conditioned medium was incubated with nonimmune rabbit serum or PBS. Data are means $( \pm S D)$ of three experiments each with duplicate determinations. The average values of PAF acetylhydrolase and LCAT activity in control experiments were $9 \pm 3.2 \mathrm{pmol} / \mathrm{min}$ per $\mathrm{mg}$ cell protein and $0.9 \pm 0.28 \mathrm{nmol} / \mathrm{h}$ per $\mathrm{mg}$ cell protein, respectively.

enzyme specific for PAF since it is inactive against similar compounds with a side chain longer than four carbons at the $s n-2$ position of the molecule (5). This enzyme does not require $\mathrm{Ca}^{++}$, and is inactivated irreversibly by DFP. Both intra- and extracellular forms of the enzyme are known, and the former, but not the latter, is inactivated by hydrolysis with trypsin and other proteases (6). Inhibition by DFP, $\mathrm{Ca}^{++}$independence, and resistance to pretreatment with trypsin or pronase support the identification of the enzyme secreted by HepG 2 cells as the extracellular form of PAF acetylhydrolase. Although PAF is a substrate for the more common form of phospholipase $A_{2}$ (38), this enzyme does not account for the activity in HepG2-conditioned medium since BPB and exclusion of $\mathrm{Ca}^{++}$from the reaction mixture did not affect the activity. The identification of this enzyme as PAF acetylhydrolase is also supported by the results of experiments examining the substrate specificity. The presence of an excess of phospholipids other than PAF in the reaction did not interfere with the hydrolysis of PAF.

Separation of HepG2-conditioned medium by gel filtration disclosed that PAF acetylhydrolase had an apparent molecular weight similar to plasma lipoproteins and that the activity was

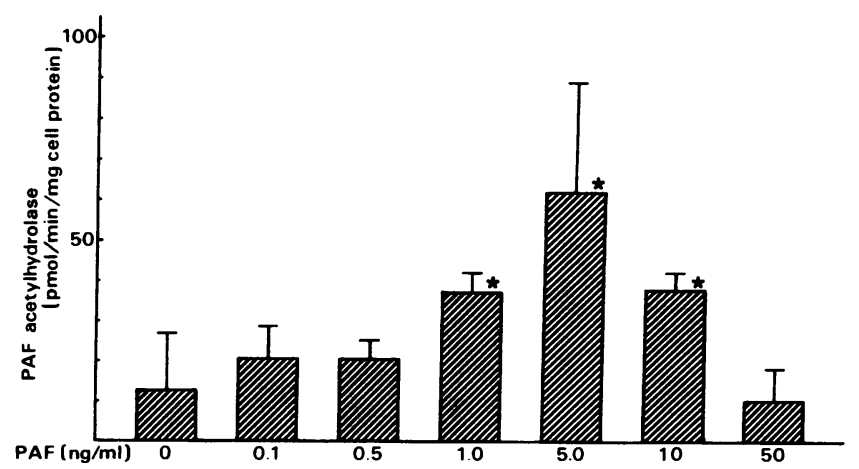

Figure 4. The effect of PAF on the secretion of PAF acetylhydrolase by HepG2 cells. PAF was dissolved in PBS containing $2.5 \mathrm{mg} / \mathrm{ml}$ fatty acid-free HSA and added to the serum-free culture medium. After $24 \mathrm{~h}$ the medium was recovered and assayed for PAF acetylhydrolase. Average values of five experiments are shown. The vertical bars indicate standard deviation. *Significantly higher than the control value $(P<0.01$, based on Student's $t$ test $)$. 
Table III. Effect of CV-3988 on the PAF-induced Stimulation of the Production of PAF Acetylhydrolase by HepG2 Cells

\begin{tabular}{ccc}
\hline CV-3988 & PAF & $\begin{array}{c}\text { PAF acetylhydrolase } \\
\text { (percent of control) }\end{array}$ \\
\hline$\mu M$ & $n M$ & \\
1 & 0 & $112 \pm 16.7$ \\
0 & 9 & $270 \pm 47.6$ \\
1 & 9 & $93 \pm 22.0$ \\
\hline
\end{tabular}

HepG2 cells were incubated with serum-free medium containing 1 $\mu \mathrm{M} \mathrm{CV}-3988$ for $1 \mathrm{~h}$ before the addition of PAF. After $24 \mathrm{~h}$ the conditioned media were collected and assayed for PAF acetylhydrolase activity. Data are means $( \pm \mathrm{SD})$ of three experiments each with duplicate determinations. The mean \pm SD of PAF acetylhydrolase activity in control experiments was $25 \pm 9.7 \mathrm{pmol} / \mathrm{min}$ per $\mathrm{mg}$ cell protein.

coeluted with apolipoproteins. These results imply that HepG2 cells secrete PAF acetylhydrolase as a complex with lipoproteins.

HepG2 cells have been shown to produce LCAT (23) and the phospholipase $A_{2}$ activity of this enzyme could have accounted for the PAF hydrolysis by HepG2-conditioned medium. In the gel permeation chromatography LCAT, in the conditioned medium, has been separated with a molecular size (23) similar to the PAF hydrolyzing activity found in this study. However, this possibility was excluded since the PAF hydrolyzing activity was almost completely precipitated with an antibody against PAF acetylhydrolase while an antibody against LCAT did not exert any effect.

Plasma PAF acetylhydrolase activity has been shown to be higher in patients with dyslipoproteinemia (7) and atherosclerotic peripheral vascular disease (8), and lower in asthma (11). Also, this enzyme activity in plasma has been shown to correlate with the levels of $\operatorname{LDL}(9,39)$. In our previous studies, plasma PAF acetylhydrolase activity was higher in patients with ischemic stroke (9) or essential hypertension (10) without any significant changes in plasma lipoproteins. We suggested that the increased enzyme activity in plasma of these patients

Table IV. Effects of PAF and Cycloheximide on the Incorporation of $\left[{ }^{35} \mathrm{~S}\right]$ Methionine into PAF Acetylhydrolase Secreted by HepG2 Cells

\begin{tabular}{cccc}
\hline PAF & Cycloheximide & Specific labeling & LDH release \\
\hline$n M$ & $\mu g / m l$ & fmol/mg cell protein & $U / m g$ cell protein \\
0 & 0 & $3.9 \pm 1.8(0.22)^{*}$ & $147 \pm 16$ \\
0 & 10 & $0.5 \pm 0.2(0.40)$ & $125 \pm 13$ \\
9 & 0 & $9.6 \pm 4.2(0.30)^{*}$ & $101 \pm 18$ \\
9 & 10 & $1.2 \pm 0.4(0.24)$ & $132 \pm 30$
\end{tabular}

HepG2 cells were incubated for $24 \mathrm{~h}$ with $1 \mathrm{MBq} / \mathrm{ml}\left[{ }^{35}\right.$ S $]$ methionine in serum- and methionine-free MEM. The conditioned medium was collected, and PAF acetylhydrolase was separated by immunoprecipitation and counted. Each value represents mean $\pm S D$ of seven experiments each with duplicate determinations. The numbers in parentheses are percent of total labeling of secreted proteins. ${ }^{*} P<0.01$.

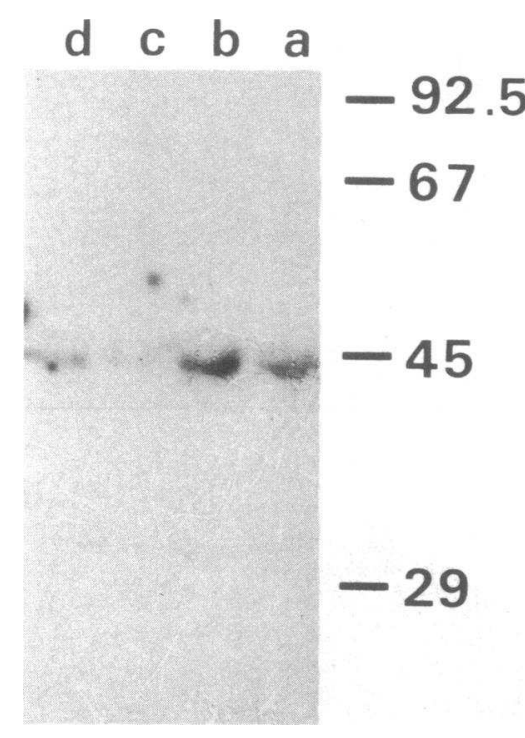

Figure 5. Incorporation of $\left[{ }^{35}\right.$ S]methionine into PAF acetylhydrolase secreted by HepG2 cells. HepG2 cells were incubated with $\left[{ }^{35} \mathrm{~S}\right]-$ methionine and PAF acetylhydrolase were separated by immunoprecipitation using anti-PAF acetylhydrolase antibody and protein A-Sepharose. The immunoprecipitates were separated by SDSPAGE. The gel was enhanced with diphenyloxazole, dried, and exposed to a film for $7 \mathrm{~d}$ at $-80^{\circ} \mathrm{C}$. Lane $a$, control; lane $b$, Hep

G2 cells labeled in the presence of $9 \mathrm{nM}$ PAF; lane $c$ and $d, 10 \mu \mathrm{g} / \mathrm{ml}$ cycloheximide was added in the presence $(c)$ or absence $(d)$ of 9 nM PAF.

was an adaptation to an increased PAF production $(9,10)$. Although such a view has to be tested by further studies, our finding of the enhanced PAF acetylhydrolase secretion in response to PAF supports our previous hypothesis. This effect of PAF is specific since it was abolished by CV-3988 and lysoPAF or egg yolk PC did not stimulate the secretion.

The stimulatory effect of PAF on the production of PAF acetylhydrolase was confirmed by metabolic labeling with $\left[{ }^{35}\right.$ S $]$ methionine. PAF enhanced the secretion of $\left[{ }^{35}\right.$ S $]$ methionine-labeled PAF acetylhydrolase, and inhibition of protein synthesis with cycloheximide blocked both the basal and PAFstimulated production of the enzyme. Since the presence of these compounds during conditioning did not increase the release of LDH, the possible liberation of intracellular PAF acetylhydrolase due to cytolysis was excluded.

In summary, HepG2 cells produce PAF acetylhydrolase and secrete it as a complex with lipoproteins, and PAF stimulates this secretion. The liver may be one of the important sources of plasma PAF acetylhydrolase.

\section{Acknowledgments}

We thank Drs. Stephen M. Prescott, Thomas M. McIntyre, and Diana M. Stafforini of the University of Utah for a critical review of this manuscript and for providing an antibody against PAF acetylhydrolase.

We also thank the Central Research Division, Takeda Chemical Industries for CV-3988.

\section{References}

1. Snyder, F. 1985. Chemical and biochemical aspects of platelet activating factor: a novel class of acetylated ether-linked choline-phospholipids. Med. Res Rev. 5:107-140.

2. Hanahan, D. J. 1986. Platelet activating factor: a biologically active phosphoglyceride. Annu. Rev. Biochem. 55:483-509.

3. Hanahan, D. J. C. A. Demopoulos, J. Liehr, and R. N. Pinckard. 1980 Identification of platelet activating factor isolated from rabbit basophils as acetyl glyceryl ether phosphorylcholine. J. Biol. Chem. 255:5514-5516. 
4. Farr, R. S., C. P. Cox, M. L. Wardlow, and R. Jorgensen. 1980. Preliminary studies of an acid-labile factor (ALF) in human sera that inactivates platelet-activating factor (PAF). Clin. Immunol. Immunopathol. 15:318-330.

5. Blank, M. L., T. Lee, V. Fitzgerald, and F. Snyder. 1981. A specific acetylhydrolase for 1-alkyl-2-acetyl-sn-glycero-3-phosphocholine (a hypotensive and platelet-activating lipid). J. Biol. Chem. 256:175-178.

6. Blank, M. L., M. N. Hall, E. A. Cress, and F. Snyder. 1983. Inactivation of 1-alkyl-2-acetyl-sn-glycero-3-phosphocholine by a plasma acetylhydrolase: higher activities in hypertensive rats. Biochem. Biophys. Res. Commun. 113:666671 .

7. Pritchard, P. H., A. Chonn, and C. C. H. Yeung. 1985. The degradation of platelet-activating factor in the plasma of a patient with familial high density lipoprotein deficiency (Tangier disease). Blood. 66:1476-1478.

8. Ostermann, G., K. Rühling, K. Zabel-Langhennig, L. Winkler, B. Schlag, and U. Till. 1987. Plasma from atherosclerotic patients exerts an increased degradation of platelet-activating factor. Thromb. Res. 47:279-285.

9. Satoh, K., T. Imaizumi, Y. Kawamura, H. Yoshida, S. Takamatsu, S. Mizuno, B. Shoji, and M. Takamatsu. 1988. Activity of platelet-activating factor (PAF) acetylhydrolase in plasma from patients with ischemic cerebrovascular disease. Prostaglandins. 35:685-698.

10. Satoh, K., T. Imaizumi, Y. Kawamura, H. Yoshida, S. Takamatsu, and M. Takamatsu. 1989. Increased activity of the platelet-activating factor acetylhydrolase in plasma low density lipoprotein from patients with essential hypertension. Prostaglandins. 37:673-682.

11. Miwa, M. T. Miyake, T. Yamanaka, J. Sugatani, Y. Suzuki, S. Sakata, Y. Araki, and M. Matsumoto. 1988. Characterization of serum platelet-activating factor (PAF) acetylhydrolase. Correlation of serum PAF acetylhydrolase and respiratory symptoms in asthmatic children. J. Clin. Invest. 82:1983-1991.

12. Maki, N., D. R. Hoffman, and J. M. Johnston. 1988. Platelet-activating factor acetylhydrolase activity in maternal, fetal, and newborn rabbit plasma during pregnancy and lactation. Proc. Natl. Acad. Sci. USA. 85:728-732.

13. Stafforini, D. M., T. M. McIntyre, E. Carter, and S. M. Prescott. 1987 Human plasma platelet-activating factor acetylhydrolase. Association with lipoprotein particles and role in the degradation of platelet-activating factor. J. Biol. Chem. 262:4215-4222.

14. Ostermann, G., H.-P. Kertscher, L. Winkler, B. Schlag, K. Rühling, and U. Till. 1986. The role of lipoproteins in the degradation of platelet-activating factor. Thromb. Res. 44:303-314.

15. Aden, D. P., A. Fogel, S. Plotkin, I. Damjanov, and B. B. Knowles. 1979. Controlled synthesis of HBsAg in a differentiated human liver carcinoma-derived cell line. Nature (Lond.). 282:615-616.

16. Knowels, B. B., C. C. Howe, and D. P. Aden. 1980. Human hepatocellular carcinoma cell lines secrete the major plasma proteins and hepatitis B surface antigen. Science (Wash. DC). 209:497-499.

17. Schwartz, A. L., S. E. Fridovich, B. B. Knowels, and H. F. Lodish. 1981. Characterization of the asialoglycoprotein receptor in a continuous hepatoma cell line. J. Biol. Chem. 256:8878-8881.

18. Rash, J. M., G. H. Rothblatt, and C. E. Sparks. 1981. Lipoprotein apolipoprotein synthesis by human hepatoma cells in culture. Biochim. Biophys. Acta. 666:294-298.

19. Zannis, V. I., J. L. Breslow, T. R. San Giacomo, D. P. Aden, and B. B. Knowels. 1981. Characterization of the major apolipoproteins secreted by two human hepatoma cell lines. Biochemistry. 20:7089-7096.

20. Morris, K. M., G. Goldberger, H. R. Colten, D. P. Aden, and B. B. Know- els. 1982. Biosynthesis and processing of a human precursor complement protein, pro-Ca, in a hepatoma-derived cell line. Science (Wash. DC). 215:399-400.

21. Marinari, L., C. M. Lenich, and A. C. Ross. 1987. Production and secretion of retinol-binding protein by a human hepatoma cell line, HepG2. J. Lipid Res. 28:941-948.

22. Swenson, T. L., J. S. Simmons, C. B. Hesler, C. Bisgaier, and A. R. Tall. 1987. Cholesteryl ester transfer protein is secreted by HepG2 cells and contains asparagine-linked carbohydrate and sialic acid. J. Biol. Chem. 262:16271-16274.

23. Chen, C.-H., T. H. Forte, B. E. Cahoon, R. N. Thrift, and J. J. Albers. 1986. Synthesis and secretion of lecithin-cholesterol acyltransferase by the human hepatoma cell line HepG2. Biochim. Biophys. Acta. 877:433-439.

24. Elstad M. R. D. M. Stafforini, T. M. McIntyre, S. M. Prescott, and G. A. Zimmerman. 1989. Platelet-activating factor acetylhydrolase increases during macrophage differentiation. A novel mechanism that regulates accumulation of platelet-activating factor. J. Biol. Chem. 264:8467-8470.

25. Khalil, A., J. Farooqui, and A. M. Scanu. 1986. Antigenic relatedness between human lecithin-cholesterol acyltransferase and phospholipases of the $A_{2}$ family. Biochim. Biophys. Acta. 878:127-130.

26. Terashita, Z., Y. Imura, and K. Nishikawa. 1985. Inhibition by CV-3988 of the binding of $\left[{ }^{3} \mathrm{H}\right]$-platelet activating factor (PAF) to the platelet. Biochem. Pharmacol. 34:1491-1495.

27. Patterson, M. K. 1979. Measurement of growth and viability of cells in culture. Methods Enzymol. 58:141-152.

28. Stafforini, D. M., S. M. Prescott, and T. M. McIntyre. 1987. Human plasma platelet-activating factor acetylhydrolase. Purification and properties. $J$. Biol. Chem. 262:4223-4230.

29. Volwerk, J. J., W. A. Pieterson, and G. H. de Haas. 1974. Histidine at the active site of phospholipase $A_{2}$. Biochemistry. 13:1446-1454.

30. Okazaki, M., Y. Ohno, and I. Hara. 1980. High-performance aqueous gel permeation chromatography of human serum lipoproteins. J. Chromatogr. 221:257-264.

31. Chen, C., and J. J. Albers. 1982. Characterization of proteoliposomes containing apoprotein A-I: a new substrate for the measurement of lecithin:cholesterol acyltransferase activity. J. Lipid Res. 23:680-691.

32. Verdery, R. B., and S. Gatt. 1981. Assay for lecithin:cholesterol acyltransferase. Methods Enzymol. 72:375-384.

33. Goding, J. W. 1976. Conjugation of antibodies with fluorochromes: modifications to the standard methods. J. Immunol. Methods. 13:215-226.

34. Laemmli, U. K. 1970. Cleavage of structural proteins during the assembly of the head of bacteriophage $\mathrm{T}_{4}$. J. Biol. Chem. 227:680-685.

35. Weber, K., and M. Osborn. 1969. The reliability of molecular weight determinations by dodecyl sulfate-polyacrylamide gel electrophoresis. J. Biol. Chem. 244:4406-4412.

36. Tolman, K. G., P. Peterson, P. Gray, and S. P. Hammer. 1978. Hepatotoxicity of salicylates in monolayer cell cultures. Gastroenterology. 74:205-208.

37. Lowry, O., N. Rosebrough, A. Farr, and R. Randall. 1951. Protein measurement with the Folin phenol reagent. J. Biol. Chem. 193:265-275.

38. Prescott, S. M., G. A. Zimmerman, and T. M. McIntyre. 1984. Human endothelial cells in culture produce platelet-activating factor (1-alkyl-2-acetyl-snglycero-3-phosphocholine) when stimulated with thrombin. Proc. Natl. Acad. Sci. USA. 81:3534-3538.

39. Carter, M. E., L. Wu, D. M. Stafforini, S. C. Hunt, R. R. Williams, T. M. McIntyre, G. A. Zimmerman, and S. M. Prescott. 1988. Platelet-activating factor acetylhydrolase correlates with plasma lipoproteins. Arteriosclerosis. 8:712a. (Abstr.) 